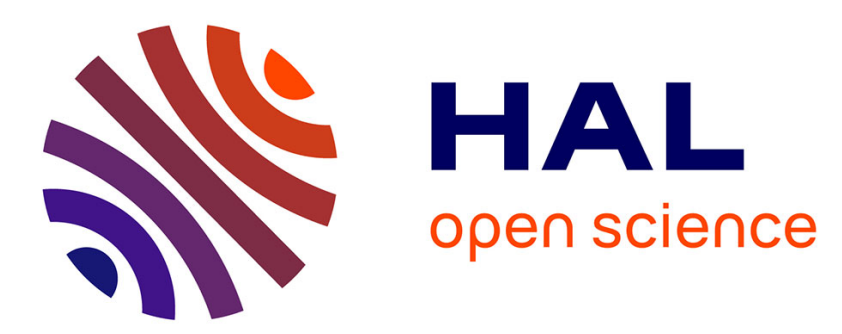

\title{
A simple technique to eliminate ethylene emissions from biochar amendment in agriculture
} Will Fulton, Myles Gray, Fredrick Prahl, Markus Kleber

\section{To cite this version:}

Will Fulton, Myles Gray, Fredrick Prahl, Markus Kleber. A simple technique to eliminate ethylene emissions from biochar amendment in agriculture. Agronomy for Sustainable Development, 2013, 33 (3), pp.469-474. 10.1007/s13593-012-0118-5 . hal-01201361

\section{HAL Id: hal-01201361 \\ https://hal.science/hal-01201361}

Submitted on 17 Sep 2015

HAL is a multi-disciplinary open access archive for the deposit and dissemination of scientific research documents, whether they are published or not. The documents may come from teaching and research institutions in France or abroad, or from public or private research centers.
L'archive ouverte pluridisciplinaire HAL, est destinée au dépôt et à la diffusion de documents scientifiques de niveau recherche, publiés ou non, émanant des établissements d'enseignement et de recherche français ou étrangers, des laboratoires publics ou privés. 


\title{
A simple technique to eliminate ethylene emissions from biochar amendment in agriculture
}

\author{
Will Fulton • Myles Gray • Fredrick Prahl • Markus Kleber
}

Accepted: 23 September 2012 /Published online: 17 October 2012

(C) INRA and Springer-Verlag France 2012
We conclude that this simple post-production handling technique renders biochars safe for use as nursery and greenhouse potting amendments, possibly replacing environmentally expensive expanded vermiculite and/or peat.

Keywords Biochars $\cdot$ Ethylene $\cdot$ Vermiculite $\cdot$ Peat Greenhouse $\cdot$ Horticultural nursery $\cdot$ Heating greenhouses · Thermal energy

\section{Introduction}

Biochars have been shown to have several desirable effects as a soil amendment. They can increase water retention and cation exchange capacity (Lehmann and Joseph 2009). The high surface area and porosity of biochars can also provide enhanced habitat for critical soil microbiology (Lehmann et al. 2011).

Because of these potentially beneficial effects, biochars have been considered as substitutes for vermiculite or peat in horticultural nurseries. While all mined materials (such as vermiculite and peat moss) are finite resources and therefore subject to depletion and eventual price increases, biochar is produced from renewable organic waste streams. Additionally, on-farm pyrolytic production of biochars can be achieved while simultaneously mitigating heating costs. After initial thermal input, pyrolysis evolves gasses that can be used to maintain its own temperature requirements, while also providing heat.

Peat moss and vermiculite, common nursery potting amendments, have additional environmental costs. Vermiculite must be exfoliated at temperatures exceeding $900{ }^{\circ} \mathrm{C}$ and is often shipped great distances. Peat mining involves the draining and destruction of sensitive wetlands and must also be shipped. Replacing such products with biochars produced onsite from locally available waste biomass, with associated capture of process heat, would be a boon not only to nurseries, but to
Department of Crop and Soil Science, Oregon State University, 3017 Agricultural and Life Science Building,

Corvallis, OR 97331, USA

e-mail: will.fulton@oregonstate.edu

\section{F. Prahl}

College of Earth, Ocean, and Atmospheric Sciences,

Oregon State University,

104 CEOAS Administration Building,

Corvallis, OR 97331-5503, USA 
the environment as well. Our objective for this research project was to determine whether biochars could be safely used as potting amendment.

Before nursery operators begin substituting biochars for other potting amendments, however, they must know that there will be no adverse effects to plant growth. While testing assorted biochars for their abilities to suppress emissions of methane and nitrous oxide $\left(\mathrm{N}_{2} \mathrm{O}\right)$, Spokas et al. (2010) discovered that the same biochars that suppressed $\mathrm{N}_{2} \mathrm{O}$ emissions also stimulated soil ethylene emissions. Additionally, they observed that this was the case whether or not the biochars were in physical contact with the soil.

Ethylene, $\mathrm{C}_{2} \mathrm{H}_{4}$, the smallest of alkenes, is a plant hormone which ordinarily occurs in low concentrations in most plant systems. However, its importance as a plant hormone varies between plant species and over the course of plant development stages, in a host of complex ways that have the potential to interfere with the expected developmental patterns of nursery plants (Fig. 1).

The effects of ethylene on plants in greenhouses have been observed from atmospheric concentrations as low as $10 \mathrm{ppb}$ (Abeles et al. 1992). Neljubow (1901) was the first to demonstrate the ability of ethylene to affect tropism in plants. Since then, ethylene has been implicated in such diverse plant responses as adventitious root formation, breaking of dormancy, leaf and fruit abscission, hypertrophy, flower and leaf senescence, premature blooming, cell elongation, root and shoot growth and differentiation, induction of femaleness in dioecious flowers, nodulation, germination, increased exudations, epinasty, and premature fruit ripening (Primrose 1979; Arshad and Frankenberger 2002; Argueso et al. 2007).

Soils produce ethylene, but biologically diverse soils do not accumulate ethylene at unsaturated moisture levels because ethylene production and consumption maintain balance. Ethylene synthesis in soils is primarily biotic, but ethylene accumulation has been reported from sterile soils when $\mathrm{Fe}(\mathrm{II})$ was introduced (Arshad and Frankenberger

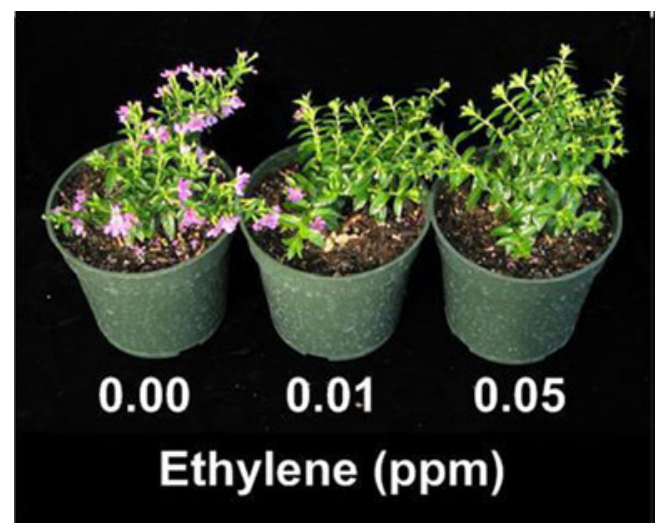

Fig. 1 An effect of ethylene on nursery plants. Image courtesy of Roland Leatherwood, Cornell University
1991). Spokas et al. (2010) observed that the ethylene emissions from soils mixed with ethylene-producing biochars were greater than the emissions defined by the sum of the parts. Again, this case was so even when the biochars were not in direct contact with the soils, but merely occupied the same vessel. Biotic ethylene production from fresh biochars would seem highly unlikely because they have just been heated to temperatures well above those known to sterilize soils. However, recent work by Spokas and Colosky (2012) detected microbial activity in several fresh biochars.

The chemical and physical characteristics of biochars are dependent on feedstock selection, pyrolysis conditions such as production temperatures and residence time, and postmanufacture handling. Porosity, surface area, the proportion of aromatic to aliphatic carbon, and other properties are known to depend on production temperature (Keiluweit et al. 2010). Following manufacture, biochars acquire oxygencontaining functional groups with time, the types and quantities of which depend upon environmental conditions (Lehmann and Joseph 2009). This observation led us to develop the fundamental motivation for our work. We hypothesized that if exposed to an oxidizing environment (e.g., stored in the open), ethylene will either degass or become oxidized and thus decline to concentrations that are no longer harmful to nursery plants.

We chose to test biochars made from two locally abundant woody waste feedstocks: Douglas fir chips and hazelnut shells. These were pyrolyzed at temperatures both below and above the observed threshold between mostly aliphatic

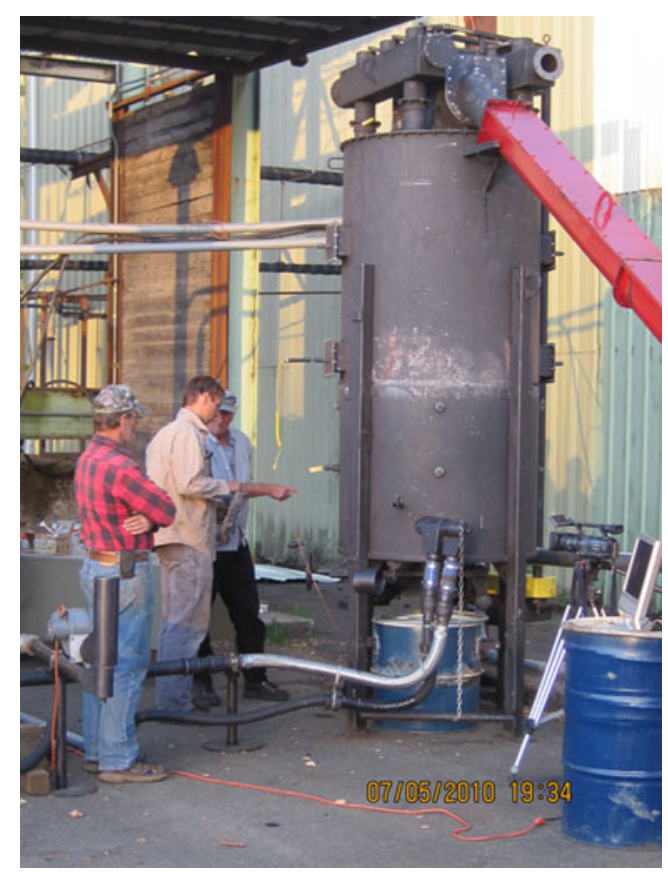

Fig. 2 The retort at Starker Forest/Thompson Timber in Philomath, Oregon, where the biochars were made 
Table 1 Characterization of the biochars used

\begin{tabular}{llllll}
\hline Feedstock & HTT & $\begin{array}{l}\text { Moisure } \\
\text { status } \\
\%\end{array}$ & $\begin{array}{l}\text { Volatile } \\
\text { matter } \\
\%\end{array}$ & $\begin{array}{l}\text { Ash } \\
\text { content } \\
\%\end{array}$ & $\begin{array}{l}\text { Fixed } \\
\text { carbon } \\
\%\end{array}$ \\
\hline Douglas fir & 370 & 1.6 & 15.6 & 1.6 & 82.7 \\
& 620 & 1.5 & 4.2 & 3.7 & 92.1 \\
Hazelnut & 370 & 2.1 & 19.4 & 2.3 & 78.3 \\
shells & 620 & 1.8 & 5.5 & 2.5 & 92.0 \\
\hline
\end{tabular}

HTT heat treatment temperature

and mostly aromatic biochar compositions (Keiluweit et al. 2010). They were then prepared to approximate nursery conditions: mixed with peat moss and moistened to simulate both field moisture capacity and saturation. (Field moisture capacity is defined as "the percentage of water remaining in a soil 2 or 3 days after its having been saturated and after free drainage has practically ceased." Brady and Weil 2008).

We hypothesized that the fresh hazelnut shell biochars would evolve ethylene, because of the biochars tested by Spokas et al. (2010), nut shell biochars yielded greatest ethylene emissions. We further hypothesized that by storing these fresh biochars for various periods of time, beginning with 90 days, they would be aged enough to eliminate ethylene emissions.

\section{Materials and methods}

Biochars were made from Douglas fir chips and from hazelnut shells by John Miedema at Thompson Timber Products/Starker Forests, Philomath, Oregon, USA, in a prototype pyrolytic retort (Fig. 2). Each feedstock was pyrolyzed to peak temperatures of either $370{ }^{\circ} \mathrm{C}$, maintained for $\sim 4 \mathrm{~min}$, or $620^{\circ} \mathrm{C}$, maintained for $\sim 15 \mathrm{~min}$ (Table 1). Portions of each of these four batches were then stored in the open air for 90 days.

Mixtures (50/50 by volume) of peat moss and each fresh biochar were prepared in $250-\mathrm{mL}$ serum bottles with polytetrafluoroethylene septa and aluminum caps. Deionized water was then added to these mixtures both to moisture saturation and to approximate field capacity. Vermiculite/ peat moss mixtures were prepared in the same ratios and moistures for comparison. Vermiculite and peat moss are commonly used for young seedlings and cuttings, and are the amendments most suitable for replacement by biochars. All samples were stored at $21.6^{\circ} \mathrm{C}$. Three replicates of each of the ten mixtures were thus prepared.
Fig. 3 Ethylene release rates (means of three replications and standard deviation) for hazelnut [HZ] chars manufactured at two temperatures $\left(370\right.$ and $\left.620^{\circ} \mathrm{C}\right)$ and incubated at two moisture levels (field capacity $[F C]$ and saturation $[$ Sat $]$ )
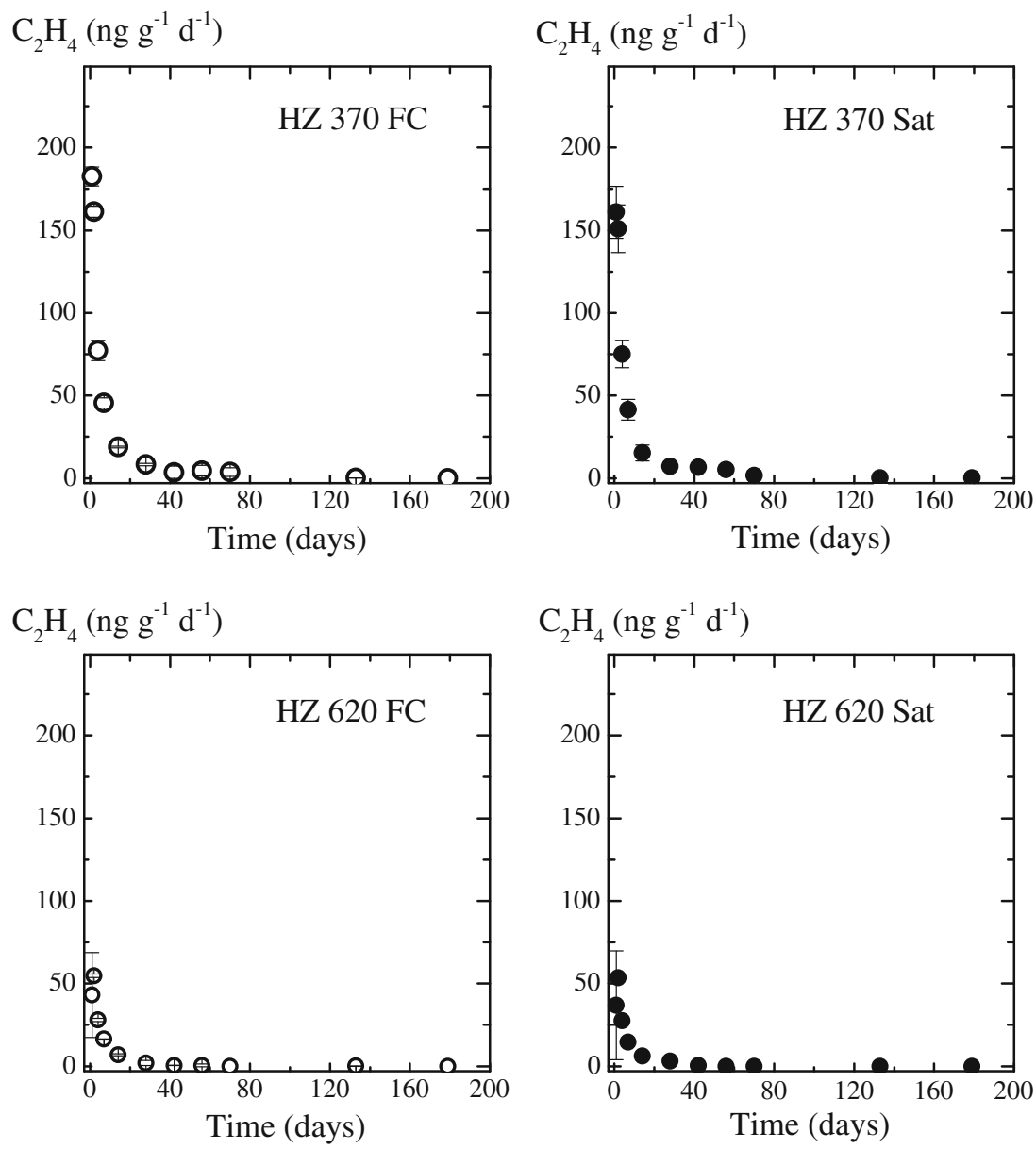
Ethylene was measured using a gas chromatograph with flame ionization detection on days $1,2,4,7,14,28,42,56$, 70,133 , and 179 of incubation. Calibration was conducted on each sampling occasion with volumetric ethylene/air mixtures of $1: 10^{3}$ (pptv) and $1: 10^{6}$ (ppmv).

Additional quantities of the four biochars were stored in the open to assess the effect of post-production handling. After storage for 90 days, the "aged" chars were then prepared in the same mixtures, manners, and quantities as for the fresh biochars and then analyzed by the same protocols. We continued storing the four biochars in case longer periods of storage were necessary to test our hypothesis.

\section{Results and discussion}

\subsection{Feedstocks}

Feedstock type was confirmed to be a determinant of biochar ethylene evolution. Biochars made from hazelnut shells emitted ethylene from the start, with accumulations diminishing as time passed (Fig. 3). Douglas fir feedstock biochars emitted smaller amounts of ethylene, and emission was apparent only on days 2 and 4 of incubation (Fig. 4).
The control samples of vermiculite and peat moss mixture accumulated no ethylene at all, until the 133rd sampling day, when the field capacity vermiculite/peat moss mixtures were recorded at levels similar to the lowest threshold values known to affect plant growth. By this time, ethylene accumulation below threshold values was observed even for the $370{ }^{\circ} \mathrm{C}$ hazelnut shell biochars. The vermiculite/peat moss mixtures were still accumulating marginal amounts of ethylene on day 179, the final sampling.

\subsection{Heat treatment temperature}

The hazelnut shell biochars pyrolyzed to a peak temperature of $370{ }^{\circ} \mathrm{C}$ emitted two to three times as much ethylene as the same feedstock pyrolyzed to peak temperatures of $620^{\circ} \mathrm{C}$. The 620 and $370{ }^{\circ} \mathrm{C}$ Douglas fir biochars emitted relatively equivalent, low-level amounts of ethylene during their brief period of emission.

\subsection{Moisture}

Ethylene emissions from the moisture-saturated samples tended to be initially lower than those from the unsaturated samples, but the difference was not significant. On day 133,
Fig. 4 Ethylene release rates (means of three replications and standard deviation) for Douglas fir $[D F]$ chars manufactured at two temperatures (370 and $620^{\circ} \mathrm{C}$ ) and incubated at two moisture levels (field capacity $[F C]$ and saturation $[S a t])$
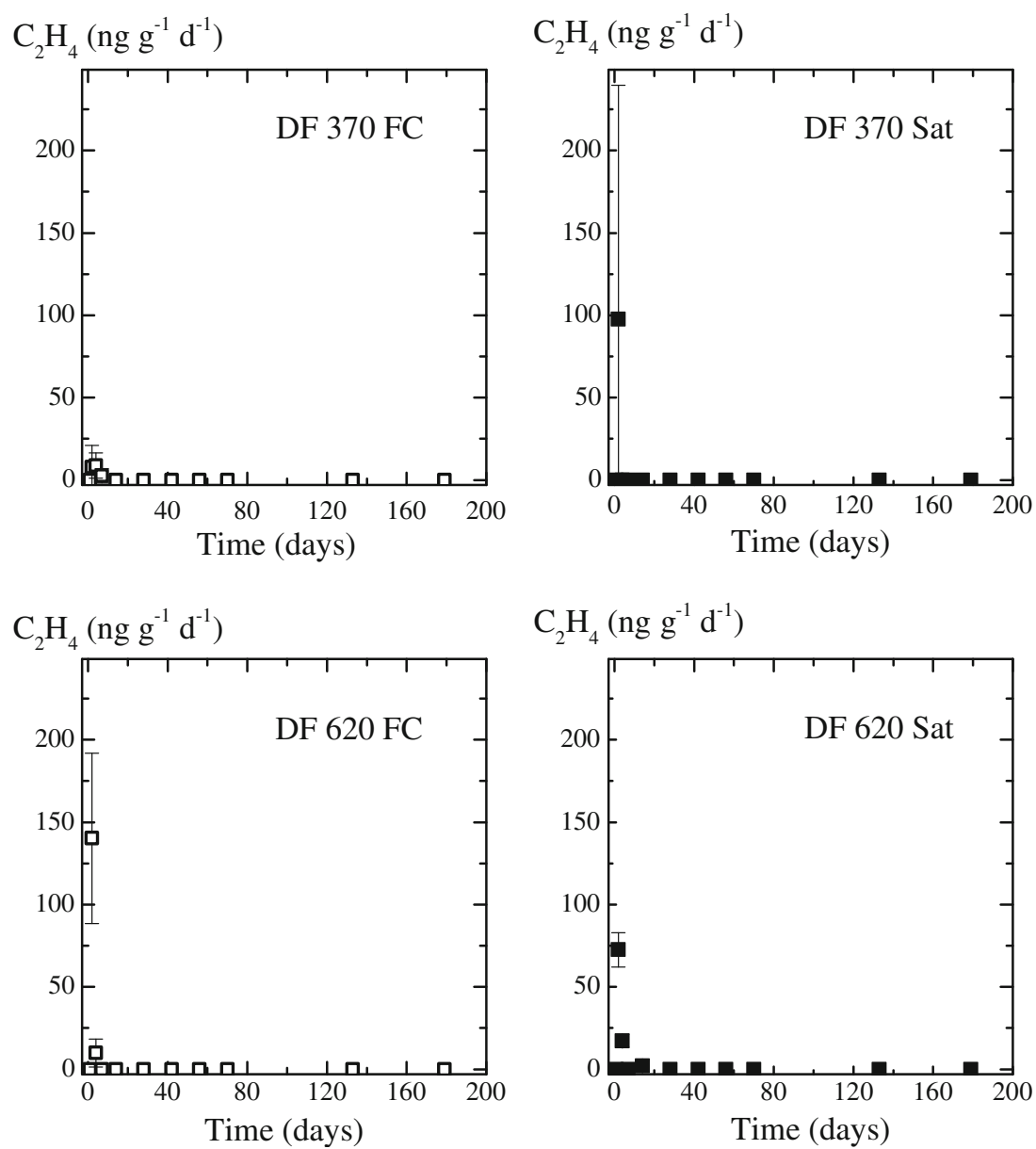
however, when the vermiculite/peat moss mixture first began to record ethylene accumulation, it was only from the samples that approximated field capacity, not from the water-saturated samples.

\subsection{Post-production handling}

None of the biochars that were stored in the open air for 90 days emitted any ethylene when tested in mixtures with peat moss at any time during sampling. This was the case when saturated with water and when moistened to the approximation of field capacity.

\subsection{Discussion}

We suspect that it was biochar-sorbed ethylene that accounted for the initial ethylene accumulations in our samples. While most of the ethylene evolved from soils is biotically synthesized (Arshad and Frankenberger 2002), soil ethylene can also be produced abiotically. As mentioned in the "Introduction," sterile soils have been demonstrated to accumulate ethylene following the introduction of FeII (Arshad and Frankenberger 1991); however, such was cointroduced with the amino acid L-methionine, and there is now evidence that extracellular enzymes are stabilized by clay particles (Yan et al. 2010), so the abiotic credentials of such $\mathrm{C}_{2} \mathrm{H}_{4}$ production might be arguable.

Although Spokas and Colosky (2012) detected microbial activity in fresh biochars, our results are inconsistent with biological ethylene production. For all of our biochars, highest ethylene accumulations were on the first days of testing and diminished in subsequent days, which is contrary to the lag followed by accelerating growth that is characteristic of biological activity.

It is known that methane can be oxidatively coupled to synthesize ethylene during pyrolysis (Albright et al. 1992), but this has ordinarily been observed when pyrolysis reached higher temperatures than ours. Ethylene has been produced by the dehydrogenation of ethane at pyrolysis temperatures as low as ours given the presence of certain catalysts, e.g., $\mathrm{NiO} /$ $\mathrm{Al}_{2} \mathrm{O}_{3}$ (Zhang et al. 2003).

No ethylene accumulation was observed in the vermiculite/ peat moss samples in the initial days. If any ethylene was being biotically synthesized in the peat moss, it was likely being concurrently consumed. Balance of biotic synthesis and catabolism of ethylene in soils, including forest $\mathrm{O}$ horizons, is normal (Elsgaard 2001). We found no documented reasons to conclude that the processes common to soils and litter could not be replicated in peat moss. By far, the most common substrate for biotic synthesis of ethylene is the amino acid Lmethionine, which should be present in peat moss.

Any ethylene flux as a result of ethylene production during pyrolysis would have been expected to decline once pyrolysis was completed, and diminishing concentrations are apparent in our results. Given these findings, we might conclude that no biotic ethylene synthesis occurred in our serum bottles. However, on days 133 and 179 of the incubation, we recorded an accumulation of ethylene in the vermiculite/peat moss control samples. Prior to this date, the only volatile hydrocarbon observed from the vermiculite/peat moss mixture was methane in concentrations similar to those of the ambient atmosphere, suggesting that this methane was an artifact of the experimental setup. The observed ethylene suggests that microbes had been present in the peat moss and were now actively synthesizing ethylene. Possibly then, ethylene was also being biotically synthesized in the biochar samples by this time, but due to their previous exposure to the sorbed ethylene, these mixtures may have produced sufficient ethylene-degrading populations as to prevent accumulation of this gas once the sorbed ethylene had gone away.

\section{Conclusions}

Our investigation has the following implications for the use of biochar as an amendment to potting media:

1. Fresh biochars can emit significant concentrations of ethylene. They should not be used as potting amendments in greenhouse nurseries.

2. Biochars should be stored for 3 months in the open before use as a potting medium. Exposure to an oxidizing environment (ventilated location in open air) for 90 days allows for all ethylene stored in the fresh biochar to degass and/or become oxidized, thereby leaving a safe product behind.

3. There was no indication that ethylene emissions from biochars were linked to microbial activity, rendering it unlikely that an ethylene problem could evolve at a later time.

Acknowledgments We would like to thank the Agricultural Research Fund at Oregon State University for funding our research. We would like to thank John Miedema at Starker Forests/Thompson Timber in Philomath, Oregon, USA, for manufacturing the chars, and Tom Jopson at Cal-Forest Nurseries in Etna, California, USA, and Tom Miles at T.R. Miles, Technical Consultants Inc., in Portland, Oregon, USA, for helpful advice.

\section{References}

Abeles FB, Morgan PW, Saltveit ME (1992) Ethylene in plant biology, 2nd edn. Academic, San Diego, 414 pp

Albright LF, Crynes BL, Nowak S (1992) Novel production methods for ethylene, light hydrocarbons, and aromatics. Marcel Dekker, NY 
Argueso CT, Hansen M, Kieber JJ (2007) Regulation of ethylene biosynthesis. J Plant Growth Regul 26(2):92-105. doi:10.1007/ s00344-007-0013-5

Arshad M, Frankenberger WT (1991) Effects of soil properties and trace elements on ethylene production in soils. Soil Sci 151(5):331-397

Arshad M, Frankenberger WT (2002) Ethylene: agricultural sources and applications. Kluwer/Plenum, New York

Brady NC, Weil RR (2008) The nature and properties of soils, 14th edn. Pearson-Prentice Hall, Upper Saddle River, p 934

Elsgaard L (2001) Ethylene turn-over in soil, litter and sediment. Soil Biol Biochem 33(2):249-252. doi:10.1016/s0038-0717(0)00122-X

Keiluweit M, Nico PS, Johnson MG, Kleber M (2010) Dynamic molecular structure of plant biomass-derived black carbon (biochar). Environ Sci Technol 44(4):1247-1253. doi:10.1021/es9031419

Lehmann J, Joseph S (2009) Biochar for environmental management: science and technology. Earthscan Ltd, London, 404 pp

Lehmann J, Rillig MC, Thies J, Masiello C, Hockaday WC, Crowley D (2011) Biochar effects on soil biota - a review. Soil Biol Biochem 43(9):1812-1836. doi:10.1016/j.soilbio.2011.04.022
Neljubow D (1901) Über die horizontale Nutation der Stengel von Pisum sativum und einiger anderer. Pflanzen Beih Bot Zentralbl 10:128-138

Primrose (1979) A review, ethylene and agriculture: the role of microbes. J Appl Bacteriol 46:1-25

Spokas K, Colosky E (2012) Presentation given at the US Biochar Conference held from July 30-Aug 1 at Sonoma State University, Rohnert Park, CA, USA

Spokas KA, Baker JM, Reicosky DC (2010) Ethylene: potential key for biochar amendment impacts. Plant Soil 333:443-452. doi:10.1007/s11104-010-0359-5

Yan J, Pan G, Li L, Quan G, Ding C, Luo A (2010) Adsorption, immobilization, and activity of b-glucosidase on different soil colloids. J Colloid Interface Sci 348:565-570. doi:10.1016/ j.jcis.2010.04.044

Zhang X, Liu J, Jing Y, Xie Y (2003) Support effects on the catalytic behavior of $\mathrm{NiO} / \mathrm{Al}_{2} \mathrm{O}_{3}$ for oxidative dehydrogenation of ethane to ethylene. Appl Catal A Gen 240(1-2):143-150. doi:10.1016/ s0926-860X(02)00426-X 